DOI: 10.1515/ausp-2017-0021

\title{
Passive Constructions - Strangers among L1 Speakers of Hungarian?
}

\author{
Enikő TANKÓ \\ Sapientia Hungarian University of Transylvania (Miercurea Ciuc, Romania) \\ Department of Human Sciences \\ tankoeniko@uni.sapientia.ro
}

\begin{abstract}
Does knowledge of Romanian, more exactly of Romanian passive voice, help learning the English passive construction? Or is it the other way round: knowledge of English helps students learning Romanian? Perhaps L2 and L3 mutually influence each other in the case of Hungarian students from Miercurea Ciuc?

In previous studies addressing the problems encountered by L1 speakers of Hungarian in the acquisition of the English passive voice (Tankó 2011, 2014), I presumed that possessing Romanian to various degrees represented a facilitating factor in the acquisition of the passive given that Romanian, like English, has a well-developed, explicitly-taught passive construction. Of course, speakers of Hungarian living in Romania might be influenced to some extent by their knowledge of Romanian when learning the English passive voice - yet, the question is to what extent. Thus, an important element of this study represents identifying students' level of Romanian and their production of Romanian BE-passive and $S E$-passive.
\end{abstract}

Keywords: SLA, L3 acquisition, passive voice, bilingualism

\section{Introduction}

In previous studies, I have addressed the problems encountered by L1 speakers of Hungarian in the acquisition of the English passive, having identified various Hungarian equivalents for the English passive construction (Tankó 2011, 2014, 2016). Among these equivalents, the one which resembled the English and Romanian passives was the predicative verbal adverbial construction. Based on empirical research described in the above mentioned studies, I reached to the conclusion that possessing Romanian to various degrees facilitated the acquisition of the passive in English. As some of the obtained results were only partially relevant, a more detailed analysis needed to be carried out, focusing more thoroughly on the actual level of Romanian of the subjects involved. 
In the present paper, I briefly describe the resemblance between the English and Romanian canonical passives, then point out the differences between the two languages with respect to the get-passive and the $S E$-passive. I also highlight the similarities between the various English and Romanian passive structures and the Hungarian predicative verbal adverbial construction, which is the closest equivalent of the aforementioned passive structures. Furthermore, I propose to analyse the production of Romanian be-passive and $S E$-passive in an empirical study and, based on the data obtained, to determine whether Romanian really functions as a facilitator in acquiring the English passive by native speakers of Hungarian.

\section{Theoretical background}

\subsection{On the English passive}

English has a periphrastic passive structure; it is made up of an auxiliary and the past participle of the main verb. The most common auxiliary is be, yet get appears fairly frequently, especially in spoken verbal production (Huddleston \& Pullum 2002: 1442).

(1) a. The van was stolen last night.

b. Tim got himself arrested last week.

It has been observed that be has a stative reading, while get denotes a process. The latter is punctual, and it carries an inchoative meaning (Hopper \& Thompson 1980: 252), as illustrated in example (2) below.

(2) The data is getting transferred.

Comparing the two structures, we can notice that get-passives are fully grammatical with result-oriented adverbials. In contrast, be-passives cannot be used with these result-oriented adverbs (Alexiadou 2005: 18). Compare the examples provided below:

(3) a. Jenny got sloppily dressed.

b. *The document got carefully destroyed.

What is more, get-passives can be used with the agent BY-phrase, while bepassives do not license agent BY-phrases (Alexiadou 2005: 19).

(4) a. *John is arrested by the police.

b. John got arrested by the police. $\quad$ (Alexiadou 2005: 19)

In this paragraph, I have pointed out two very distinctive differences in the use of the two types of English passive constructions regarding the agent phrase and adverbial modification. These differences between stative and dynamic reading seem to appear in the Romanian passive as well as in the Hungarian predicative verbal adverbial construction, as it will be shown in what follows. 


\subsection{On the Romanian passive}

As well as in English, in Romanian, there are two kinds of passive structures: there is the copular passive, also called the be-passive, which clearly has a stative reading, and there is the impersonal passive, or $S E$-passive, with a more dynamic reading. Consider the examples in (5) below.
a. Cărțile
au fost
plătite
(de Ioana).
books $_{\text {Nom }}$-the
were
paid
(by Ioana)

'The books were paid for (by Ioana).'

b. Cărțile s-au plătit.

books $_{\text {Nom }}$-the SE paid

'The books have been paid for.'

As opposed to English, there is a very important difference concerning the variable form of the participle in Romanian canonical passives, which agrees in number and gender with the grammatical subject, as illustrated below.

(6)
a. Ziarul
a fost
cititØ
(de Ion).
newspaper. ${ }_{\text {N.SG }}$-the
has been
$\operatorname{read}_{\text {N.SG }}$
by John

'The book has been read by John.'
b. Cartea
a fost
citită
(de Ion).

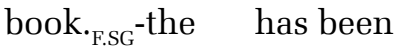
read. $_{\text {F.SG }}$
by John

'The book has been read by John.'

As Manoliu Manea (1993: 95) notices, the two kinds of Romanian passive structures behave differently if we consider adverbial modification. Manner adverbials used with Romanian $S E$-passives refer to the manner of the action named by the passive verb in general, without having in mind a certain agent BYphrase. The same type of adverbials used with be-passives refer to the manner of the action performed by the particular agent in a particular context.

(7)
a. pantalonii
s-au vândut
bine
trousers-the SE sold
well

'The trousers sold well.'

(Trebuie să mai comanzi alții.

'You have to order some more.')

$\begin{array}{lll}\text { b. pantalonii } & \text { au fost vânduți } & \text { bine } \\ \text { trousers-the } & \text { were sold } & \text { well }\end{array}$

'The trousers were well sold.'

(Ai vânzători vrednici.

'You have worthy salesmen.')

(Manoliu Manea 1993: 95)

Looking at agent-phrases, we can notice that with $S E$-passives the logical subject is completely suppressed (Dobrovie-Sorin 1998: 407). Thus, we have a generic reading in the case of $S E$-passives. Sentences with be-passives do not suppress their logical subjects. 
(8) a. Se vine târziu.

SE come late

'It is usual for everyone to come late.'

b. Se ştie adevărul.

SE know truth-the

'The truth is known.' (GLR, I)

In the present subsection, I have focused on the agent phrase and adverbial modification in the case of the two types of Romanian passive constructions. The differences between stative and dynamic reading appear to be very similar to what has been pointed out in English and what will be highlighted in Hungarian in what follows.

\subsection{On the passive in Hungarian}

In Hungarian, the first passive structure to be mentioned is the synthetic (verbal) passive, which is formed with the suffix -tat / -tet, and which is considered archaic. This type of structure appears frequently in the codices (Tóth 2000: 253), yet in contemporary Hungarian it occurs rather rarely and only with certain verbs, e.g. születik 'be born', adatik 'be given', viseltetik 'owe somebody certain feelings', foglaltatik 'be included'.

Instead of the synthetic passive, Hungarian uses a structure called the predicative verbal adverbial construction in the literature (de Groot 1987, 1989; Alberti 1996, 1998; Laczkó 1995, 2000, 2005; Tóth 2000; Bene 2005; Kertész 2005; Németh 2007; Bartos 2009; Márkus 2008). Though some linguists claim it is a passive structure, the predicative verbal adverbial construction is not as productive as the passive in English or Romanian. What is more, as we will see in what follows, only certain classes of verbs are compatible with the mentioned construction. However, in certain dialects of Hungarian, these restrictions are not as strict as in the standard Hungarian (cf. Kádár \& Németh 2010).

Interestingly, the Hungarian predicative verbal adverbial construction displays two kinds of auxiliaries. The structure with van 'to be' results in a stative reading, while the structure with the auxiliary lett/lesz 'to become' allows a more dynamic reading. In both cases, the auxiliary is followed by the adverbial participle form of the verb (ending in $-v A){ }^{1}$

(9)

$\begin{array}{llll}\text { Az ajtó } & \text { be van } & \text { csuk-va. } \\ \text { the door } & \text { perf }_{\text {in }} & \text { is } & \text { close-adv.part }\end{array}$

'The door has been closed.'

1 The capital letters of the vowels signal that they have variable forms according to the vowel harmony: -va/-ve and -ván/ -vén; the choice depends on the phonological properties of the vowels of the stem (Bartos 2009: 75). 
$\begin{array}{llll}\text { b. Az ajtó } & \text { be } & \text { lett } & \text { csuk-va. } \\ \text { the door } & \text { perf }_{\text {in }} & \text { became } & \text { close-adv.part }\end{array}$

'The door has been closed.'

As already mentioned, the Hungarian predicative verbal adverbial construction is not fully productive. It is compatible only with certain classes of verbs. Accomplishments and achievements may be freely used with the PVAC, yet states or activities are incompatible with them (Kertész 2005: 16-17). Notice that in the examples provided below the statement in (10a.) containing an accomplishment is compatible with the predicative verbal adverbial construction, while the state verb in (10a.) is perceived as ungrammatical.

(10)

$\begin{array}{lll}\text { a. }{ }^{*} \text { Mari } & \text { szeretve } & \text { van. } \\ \text { Mary } & \text { love-adv.part } & \text { is }\end{array}$

'Mary is loved.'

b. A szoba ki van takarítva.

the room out is clean-adv.part

'The room has been cleaned.'

As Kertész (2005: 2) remarks, transitives and ergatives are compatible with the predicative verbal adverbial construction (see example 11a.), yet unergative verbs are not acceptable, as illustrated in sentence (11b.) below.

(11)
a. A tó
be
van
fagyva.
the lake
perf $_{\text {in }}$ is
freeze-adv.part

'The lake is frozen.'

b. *Mari énekelve van.
Mary sing-adv.part is
*'Mary is sung.'

(Kertész 2005: 2)

Just as in the case of English and Romanian passives, one of the two types of Hungarian structures, namely the Hungarian predicative verbal adverbial construction with the auxiliary lett/lesz 'to become', has a more dynamic reading (Laczkó 1995: 190). Furthermore, it is also compatible with the agent phrase, while the same construction with the auxiliary van 'to be' does not license the presence of an overt agent BY-phrase.
a. A fal
a fiú által
lett
le-fest-ve.
the wall
the boy by
became perf $f_{\text {down }}$-paint-adv.part
'The wall got painted by the boy.'
(Laczkó 1995: 190)
b. *A fal
a fiú által
van
le-fest-ve.
the wall
the boy by is
perf $_{\text {down }}$-paint-adv.part

'The wall is painted by the boy.'

As Bartos (2009: 90) remarks, event-related modifiers are acceptable with the auxiliary lett/lesz 'to become', yet the same event-related modifiers are incompatible with the auxiliary van 'to be'. Compare the examples provided below. 
(13)

$\begin{array}{llll}{ }^{*} \text { könnyen } & \text { el } & \text { van } & \text { törve } \\ \text { easily } & \text { perf }_{\text {away }} & \text { is } & \text { break-adv.part }\end{array}$

b. könnyen el easily 'is broken easily' perf $_{\text {awav }}$

lesz

törve

will.become break-adv.part

As I have illustrated in this paragraph, in Hungarian, the two types of structures of the predicative verbal adverbial construction seem to follow the same kinds of patterns as have been pointed out in English and Romanian. Namely, there are distinct structures for stative and dynamic reading, which display very similar characteristics when it comes to the presence of the agent phrase or adverbial modification.

\subsection{Partial conclusions}

Comparing the two types of passive structures in the three languages under discussion, we may notice that the English be-passive mainly corresponds to the result state reading of the PVAC with van 'to be' and the Romanian be-passive. The English get-passive, the Romanian SE-passive, and the Hungarian PVAC with lett 'become' allow a more dynamic reading. What is more, the latter types of passives are also compatible with overtly expressed agent phrases and adverbial modification.

(14) a. The window is broken.

b. Fereastra

este spartă.

window-the . $_{\mathrm{FEM}}$ is broken $_{\text {FEM }}$

'The window is broken.'

c. Az ablak be van törve.

the window perf $_{\text {in }}$ is break-adv.part

'The window has been broken.'

(15) a. The wall got painted.

b. Peretele s-a văruit.

wall-the SE painted

'The wall got painted.'

c. A fal

le

the wall $\quad$ perf $_{\text {down }}$

'The wall got painted.'

lett

become festve.

paint-adv.part

Consequently, native speakers of Hungarian learning Romanian as their L2 and English as L3 should be able to learn and use the English and Romanian passive structures easily due to their shared characteristics. However, the empirical research described in previous studies revealed a series of difficulties in using the English passive (Tankó 2011, 2014, 2016). This is what triggered us into having a closer look at the issue. 


\section{The main question}

The main research question to be answered in the present study is whether knowledge of Romanian passive voice really helps L1 speakers of Hungarian from Miercurea Ciuc learning the English passive construction. The Hungarian predicative verbal adverbial construction, which resembles the English and Romanian passive construction the most, is not frequent in the written verbal production, and it is not taught in schools. Yet, Hungarian is still students' L1, and thus these students possess some knowledge of the notion of passive, whether consciously or not. Furthermore, Romanian and English passive are part of school instruction and the passive/passive-like structures under discussion share a number of common traits, such as productivity, as well as quite a resembling structure. The main question might be answered by shedding light upon the existence of a thorough knowledge of the Romanian passive by L1 speakers of Hungarian.

\section{The hypothesis}

Our main hypothesis is that L1 speakers of Hungarian from Miercurea Ciuc and its area possess a certain level of Romanian which includes the passive structures. Thus, knowledge of the Romanian passive has a positive influence on the acquisition of the English passive. This hypothesis has been tested in previous studies on Hungarian-Romanian bilingual speakers from Braşov (see Tankó 2011, 2014). However, the results obtained from subjects from Miercurea Ciuc were not conclusive enough as the actual level of Romanian knowledge of the subjects involved in the empirical research had not been determined.

\section{Research methodology}

In order to determine the knowledge of Romanian passive in the case of L1 Hungarian learners from Miercurea Ciuc, a number of 372 subjects, students in the $9^{\text {th }}$ and $10^{\text {th }}$ grades from four different secondary schools in the town, have been tested. We have chosen the four secondary schools according to their students' results at the national baccalaureate exams in the last four years. As such, we have chosen two theoretical secondary schools with the highest scores and two secondary schools with a technological profile displaying more humble results at the mentioned national tests. Actually, the test was part of a larger project which aimed at testing students' level of Romanian. ${ }^{2}$ To this purpose, we have used a

2 Special thanks goes to my brother, József Tankó, whom I have worked with in testing students' level of Romanian. Part of the results have been included in his study, Strategii de diminuare a 
test designed by the Department of Romanians from Everywhere ${ }^{3}$ and used for foreign students, respecting the Common European Framework of Reference for Languages (CEFRL). ${ }^{4}$

As a second step, students who had reached the B1/B2 level were administered a short test involving the English passive. Their task was to finish six sentences beginning with the direct object, based on some pictures, and furthermore to translate six Hungarian sentences into English. Among the sentences to be translated, there were two active sentences with the direct object in topic position, two sentences with the direct object in topic and the subject in focus position, and two sentences with the predicative verbal adverbial construction.

\section{The collected data}

Testing has been carried out during school hours. Students had to complete the Romanian level test in 50 minutes. The results of the level tests turned out to be surprising: 140 students did not even reach A1 level (38\%), 105 of them achieved A1 level (28\%), while 69 subjects attained A2 level (19\%). In other words, more than two-thirds of the tested subjects were below the A2 level, while the official point of view (i.e. national curriculum) requires at least B1 level, which would allow students to understand and analyse literary texts. ${ }^{5}$ It seems that only $15 \%$ of them possess the proper level (B1/B2) of Romanian (49 students at B1 level and 9 subjects at B2 level of Romanian), as shown in the chart below.

In the present study, I have considered only a part of the level tests, which implied dealing with Romanian passive constructions. The task was simple: the students had to rewrite five active Romanian sentences in the passive. In fact, they had to complete the passive sentence with the appropriate verb form and agent phrase, as illustrated in the example below.

(16) Alex a câştigat consursul de înot. 'Alex won the swimming race.'

Concursul de înot a fost câştigat/s-a câștigat de către Alex.

'The swimming race was won by Alex.'

barierelor lingvistice în analiza şi interpretarea textelor literare - unpublished.

3 Test available at: http://www.dprp.gov.ro/elearning/ (last visited on: 16 September 2017).

4 Further details on CEFRL are available online at: https://en.wikipedia.org/wiki/Common European_Framework_of_Reference_for_Languages.

5 The national curriculum of Romanian language and literature does not distinguish between native and non-native speakers of Romanian and requires students to understand and analyse literary texts/excerpts of C1 or C2 level during Romanian classes as well as for their final examination. The programmes for $9^{\text {th }}$ and $10^{\text {th }}$ grades are available at: http://programe.ise.ro/ (last retrieved on: 16 September 2017). 


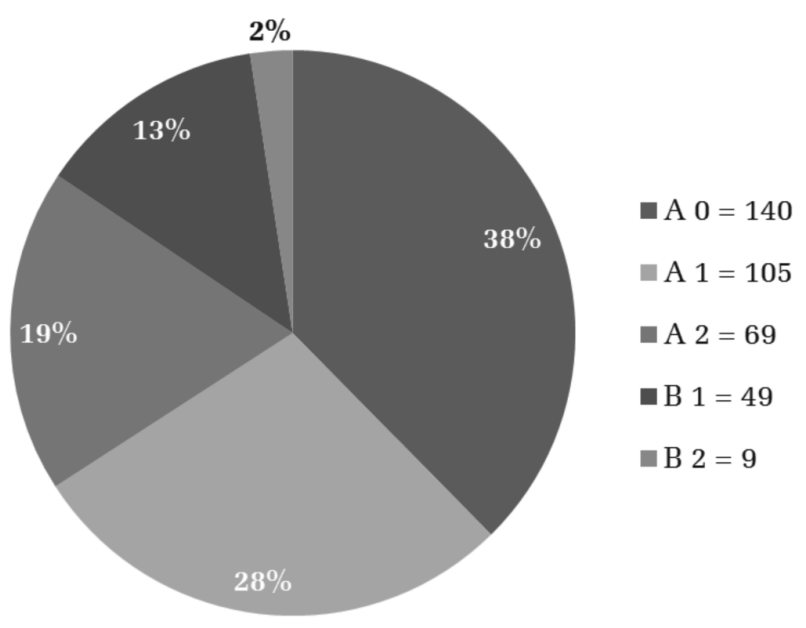

Chart 1. The results of the Romanian level tests

Among the examples provided, there were instances of $S E$-passives and bepassives as well. The data analysed shows that in fact only about $1 / 3$ of the subjects completed the task. These were the subjects who had reached the A2, $\mathrm{B} 1$, or B2 levels. This is the case because the passive voice is addressed only at A2 level.

Table 1. Data obtained on the use of Romanian passive

\begin{tabular}{cccccccc}
\hline $\begin{array}{c}\text { Number of } \\
\text { students }\end{array}$ & $\begin{array}{c}\text { Tests } \\
\text { completed }\end{array}$ & School 1 & School 2 & School 3 & School 4 & School 5 & Average \\
\hline 372 & 125 & $46(\mathbf{7})$ & $28(\mathbf{4})$ & $49(\mathbf{1 3})$ & $39(\mathbf{1 )}$ & $57(\mathbf{2 1})$ & 43.8 \\
\cline { 2 - 8 } & $33.6 \%$ & $36.8 \%$ & $22.4 \%$ & $39.2 \%$ & $31.2 \%$ & $45.6 \%$ & $35.04 \%$ \\
\cline { 2 - 8 } & - & $12.36 \%$ & $7.52 \%$ & $13.17 \%$ & $10.48 \%$ & $15.32 \%$ & $11.77 \%$ \\
\hline
\end{tabular}

The percentage of the correct answers, as compared to the total number of subjects involved in the test, is relatively low (see percentages displayed in the last row in Table 1 above). It seems that the knowledge of Romanian passive is quite poor among students from Miercurea Ciuc, L1 speakers of Hungarian (11.77\% of correct answers as compared to the total subjects involved in the test and $35.04 \%$ as compared to the number of students who actually completed the test).

As it turned out, Romanian be-passive is more commonly used among the subjects tested as opposed to $S E$-passive. This could be explained by the resemblance between the Hungarian predicative verbal adverbial construction with van 'to be' and the Romanian be-passive. Around 1/3 of the subjects managed to provide correct passive structures (28\% be-passives and $8 \% S E$-passives), 
while $61 \%$ of them committed some type of mistake and another $3 \%$ failed to provide any answer whatsoever. The results are displayed in Chart 2 below.

The main types of mistakes observed include: agreement in gender or number, problems in preserving the original tense/aspect, errors in both tense/aspect and agreement, erroneous use of the agent BY-phrase ('de'/'de către') or multiple problems (several types of problems occurring simultaneously). There were also a number of students who did not provide any answer whatsoever.

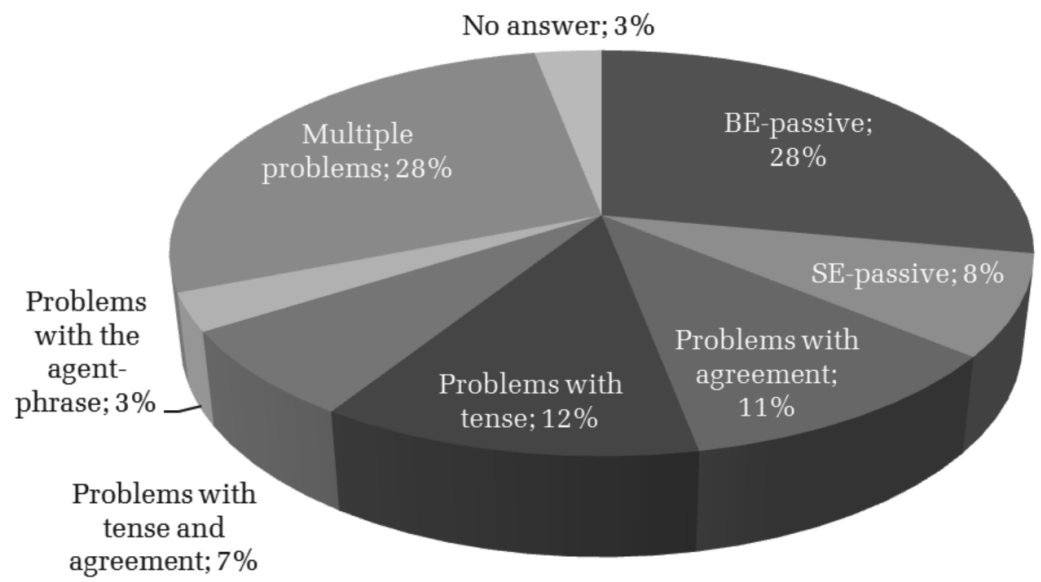

Chart 2. Results of the task involving the Romanian passive

In what follows, I will discuss each type of mistake in details, providing examples and offering possible explanations for each situation.

\subsection{Problems with agreement}

Around $11 \%$ of the tested students encountered problems of agreement between subject and predicate in number and/or gender. Note that the participial form of the main verb in the Romanian be-passive construction has to agree in number and gender with the subject. The auxiliary also has to agree in number with the subject of the sentence. Some of the erroneous examples are illustrated in what follows.

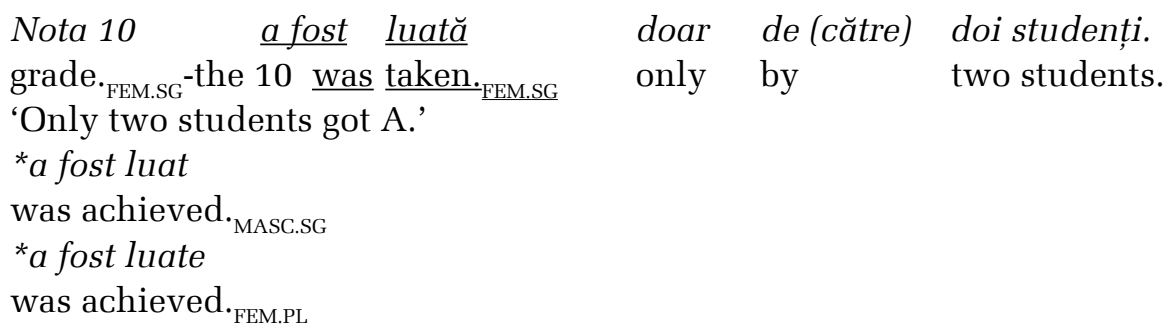


*au fost luat

were achieved. MASC.SG $_{\text {. }}$

*au fost luați

were achieved. MASC.PL $_{\text {. }}$

(18)

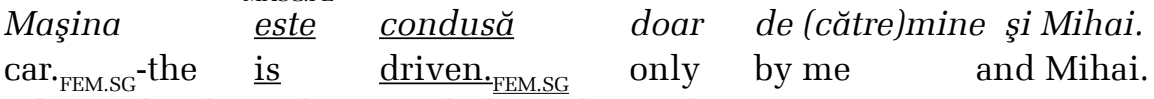

'The car has been driven only by Mihai and me.'

*este condus

is driven. ${ }_{\text {MASC:SG }}$

${ }^{*}$ este conduse

(19) Ieri

is driven. FEM.PL $_{\text {. }}$

$\begin{array}{llll}\text { Ieri } & \underline{\text { s-a căutat }}_{\text {yesterday }} \underline{\text { SE looked }}_{{ }_{\mathrm{N} . \mathrm{SG}}} \text { for } & \begin{array}{l}\text { un magazin } \\ \text { a shop. }_{{ }_{\mathrm{N} . \mathrm{SG}}}\end{array} & \begin{array}{l}\text { de electronice. } \\ \text { of electronics }\end{array}\end{array}$

'Yesterday they looked for a shop of electronics.'

${ }^{*}$ s-au căutat

SE looked. ${ }_{\text {N.PL }}$ for

The aforementioned type of agreement does not exist in the Hungarian predicative verbal adverbial construction. Consequently, it is not a surprise that L1 speakers of Hungarian committed a number of mistakes when using the Romanian passive, most probably due to negative transfer.

\subsection{Problems with tense and/or aspect and agreement}

Around $7 \%$ of the tested subjects had problems with agreement but also with maintaining the tense and/or aspect of the original active sentence. Compare the examples provided below.

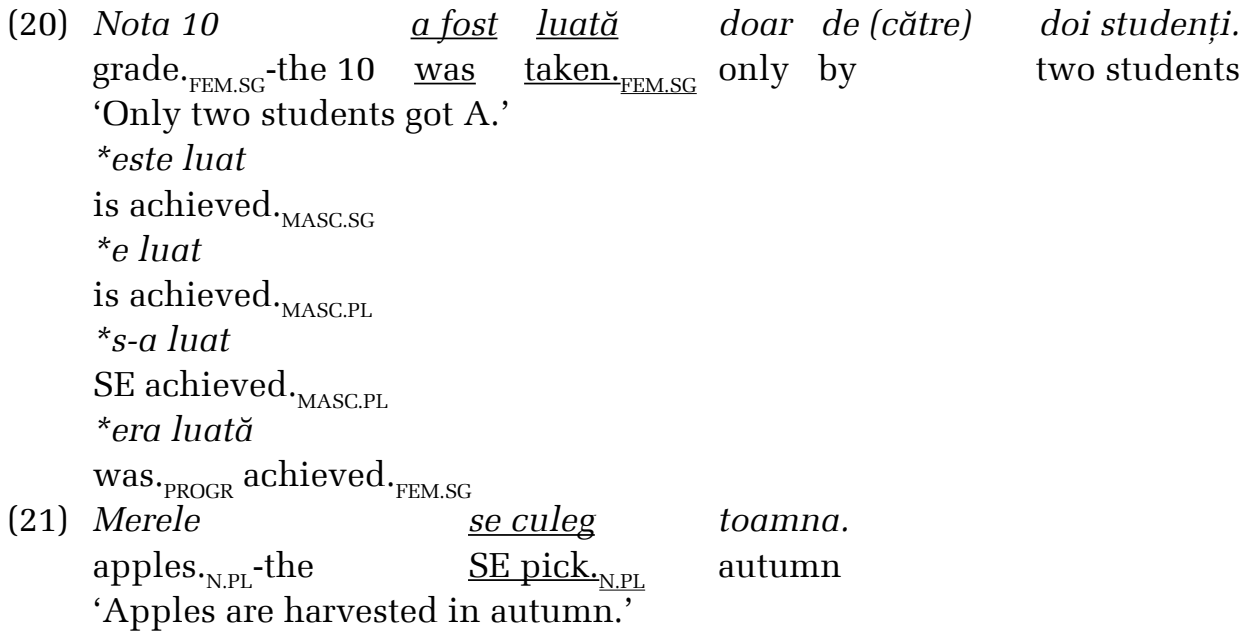


*a fost cules

was harvested. MASC.SG

${ }^{*}$ e culese

is harvested. FEM.PL

*o să fiu culese

I am going to be harvested..$_{\mathrm{FEM} . \mathrm{PL}}$

(22) $I$ Ieri s-a căutat un magazin de electronice. yesterday SE looked. $_{{ }_{N . S G}}$ for a shop. $_{\text {N.SG }}$ of electronics 'Yesterday they looked for a shop of electronics.'

*era căutată

was looked. PROGR $_{\text {for. }}$.FEM.SG

*este căutată

is looked for.

As already mentioned in the previous subsection, mistakes involving agreement can be easily accounted for by negative transfer. There is no category of grammatical gender in Hungarian. Thus, at least on a lower level of Romanian knowledge, it is difficult for L1 speakers of Hungarian to avoid mistakes of such kind.

\subsection{Problems with the agent BY-phrase}

Another type of mistake is connected to the agent BY-phrase. If we consider the examples provided in (23), it becomes clear that some of the subjects of the empirical research have difficulties in choosing the appropriate preposition for the agent.

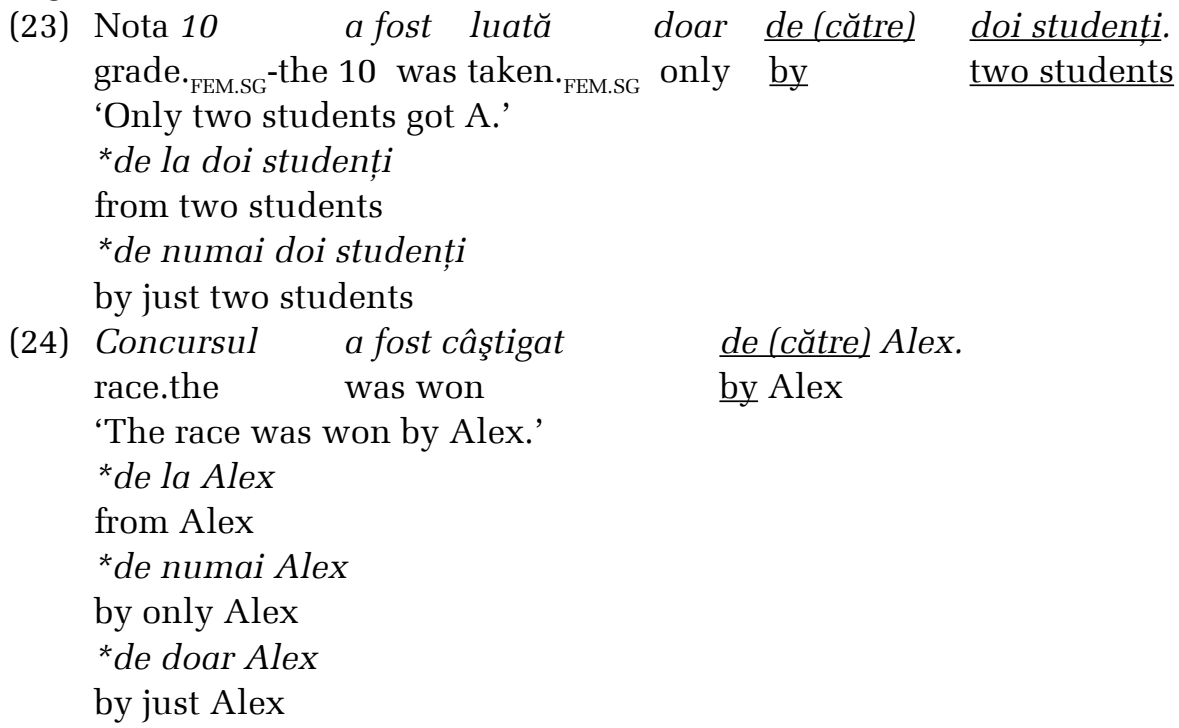




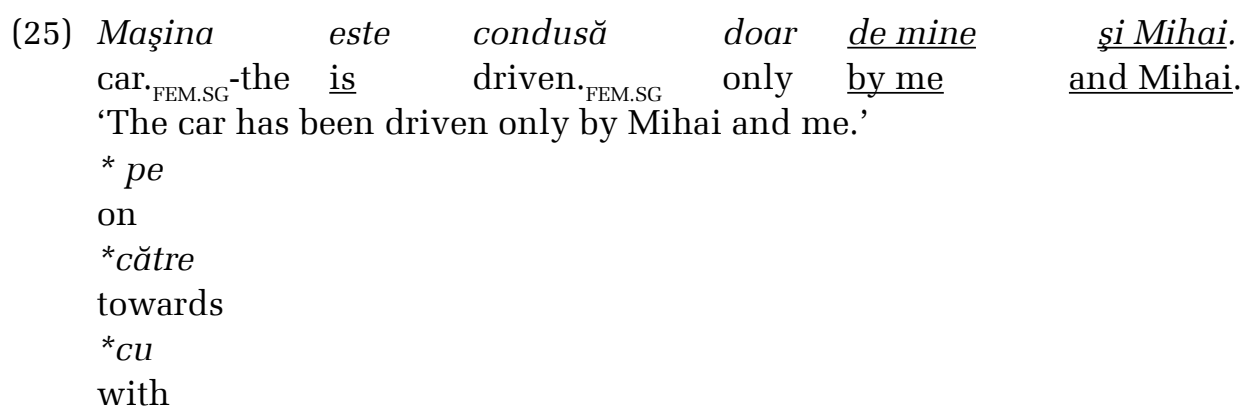

The types of mistakes displayed above can only be explained by some students' poor level of Romanian. The choice of an inappropriate preposition leads us into concluding that some of the tested subjects do not possess a thorough knowledge of the Romanian passive. Of course, this conclusion cannot be generalized as around $1 / 3$ of the subjects managed to provide correct passive structures.

\subsection{Multiple problems}

Around $28 \%$ of the subjects of our empirical research committed several types of mistakes in the same sentence. In the examples provided in (26) below, for instance, there is no agreement between the subject of the sentence and the participial verb form and, at the same time, the tense of the original sentence is not maintained. Some of the participial verb forms are erroneous (for instance, *este luă 'is took' is a difficult type of mistake to illustrate in English as it is the simple past form of the indicative used instead of the participial form).

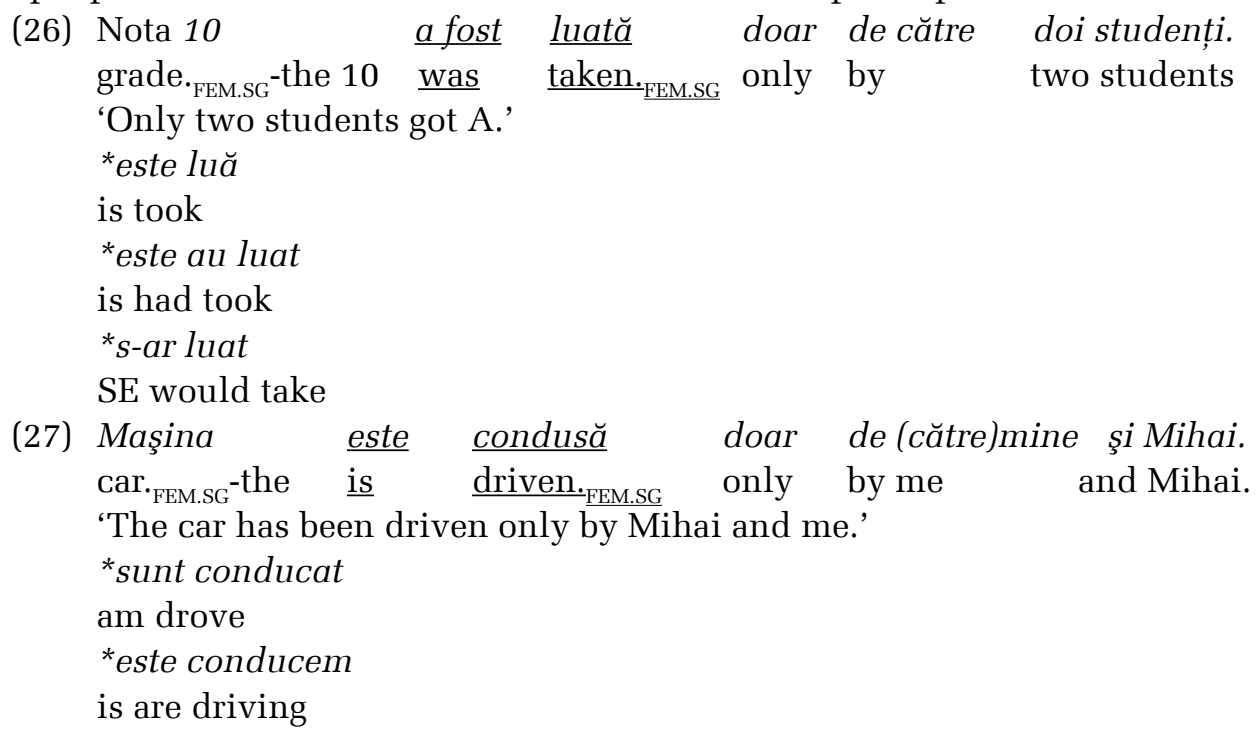


${ }^{*}$ m-am condus

I driven myself

Certain participial forms of the passivized verb proved to be impossible to translate into English, as they are inexistent verb forms in Romanian, as illustrated in the examples below. The verb a culege 'to pick' does not have any of the forms enlisted in (28).

(28)

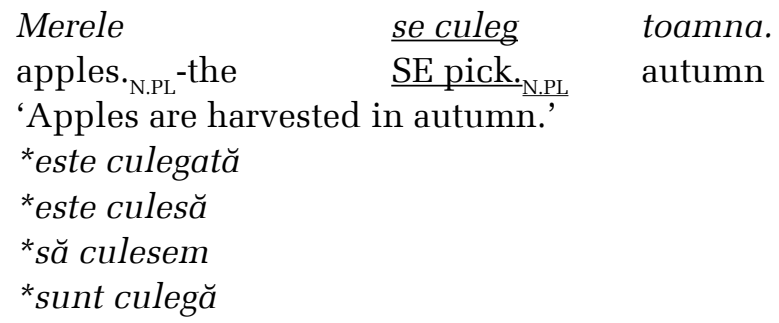

Summing up, it can be stated that, according to the test results, the level of Romanian turned out to be under expectations. As displayed in Chart 2, around $30 \%$ of the tested subjects committed several types of mistakes in the same sentence.

\subsection{Data on the English passive}

Following the test in Romanian, subjects who had attained levels B1/B2 were further administered a short test involving the passive in English. Consequently, this second part of the test was completed by a total of 58 students. Their first task was to complete a set of six sentences beginning with the direct object. They also had pictures for each sentence to guide them. In the second task, they had to translate six Hungarian sentences into English: two active sentences with the direct object in topic position, two more active sentences with the direct object in topic and the subject in focus position, and two sentences with the predicative verbal adverbial construction. They were expected to use the short or the long passive in all contexts, though this requirement was not stated in the task.

Around $68 \%$ of the tested subjects provided correct passive sentences in English in both tasks, while another $13.79 \%$ preferred active sentences. Around $6 \%$ of the students had problems with the main verb, i.e. the irregular third forms, and another $6.61 \%$ encountered problems in maintaining the tense and/ or aspect of the original Hungarian sentence. Some of the erroneous examples are illustrated in what follows.

(29) A fagyit a barátom fizette ki. the ice cream. Acc $_{\text {. }}$ the friend.my ${ }_{\mathrm{N}}$ 'The ice cream has been paid for by my friend.' paid perf $_{\text {down }}$ ${ }^{*}$ The ice cream is paid for by my friend. 
Another type of mistake was connected to the agent phrase. More exactly, approximately $3 \%$ of the subjects used the nominative form of the pronouns in the agent BY-phrase, as illustrated in (30). Another $2.87 \%$ of the subjects of our empirical research committed several types of mistakes in the same sentence; for instance, they failed to maintain the original tense and/or aspect of the Hungarian sentence and used the incorrect past participle form of the main verb, as illustrated in (31) below.

(30)
Az ablakot
ók törték be.
the window.
they $_{{ }_{\mathrm{N}}}$ broke perf $_{\text {in }}$

'The window has been broken by them.'

*The window has been broken by they.

(31) $A$
A tolvajt
elkapta
a rendôrség.
the thief. ${ }_{\text {Acc }} \quad$ perf $_{\text {away }}$.caught
the police. ${ }_{\mathrm{N}}$
'The thief was caught by the police.'
*The burglar is chaught by the police.

Comparing the results obtained in Romanian and English, we can easily notice that subjects scored better in English. They had fewer mistakes when using the English passive and provided answers for each task, as displayed in Chart 3 below.

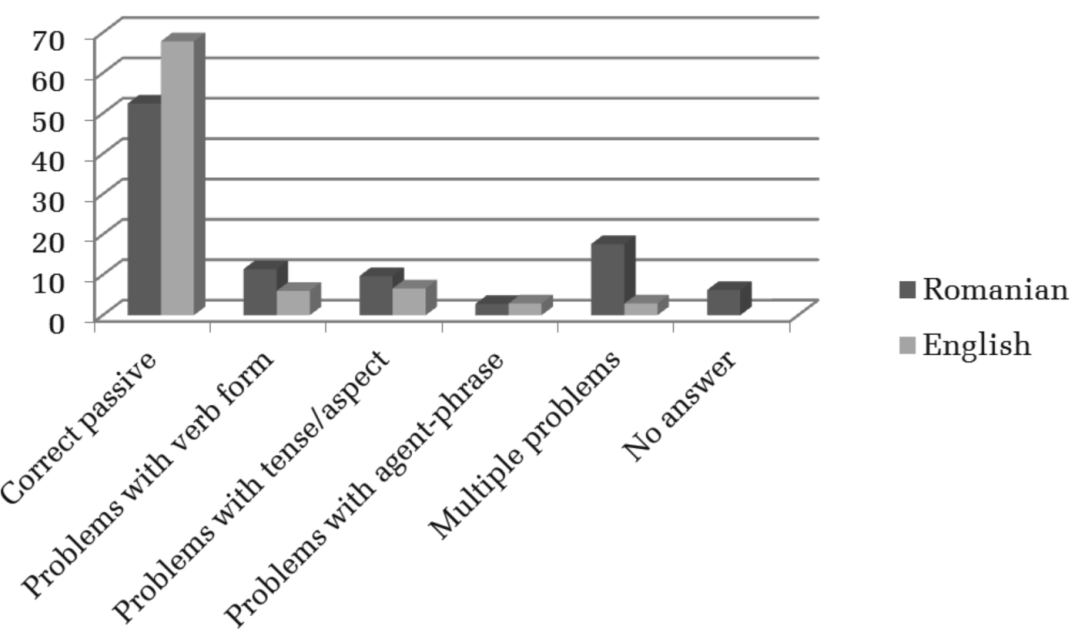

Chart 3. Results comparing the empirical data on Romanian vs English passive

In Romanian, agreement seems to be a problematic area since both the auxiliary and the participle verb form need to agree with the subject. At the same time, agreement concerns gender, as well, in addition to number and person. Since there is no grammatical gender in Hungarian, mistakes of this type can be explained by negative transfer from L1. 


\section{Conclusions}

In the present paper, I have analysed the production of Romanian be-passive and $S E$-passive, and, based on the data obtained, I have outlined students' knowledge of the Romanian passive voice. Having in mind students' scores in the Romanian proficiency test (85\% reached only levels A1/A2 or below), the percentage of correct answers (only $36 \%$ ), and the types of mistakes that occurred, it can be concluded that the majority of students, native speakers of Hungarian from Miercurea Ciuc involved in our study, do not know Romanian properly, and as such Romanian can hardly be considered a facilitator in acquiring the English passive in their case.

Only a small percentage (around 15\%) of the tested subjects can use correctly both English and Romanian passive structures. In their case, it is not clear whether Romanian influences their acquisition of the English passive, or it is the other way round, i.e. knowledge of English enabled the acquisition of Romanian passive. If we consider that some of them are Hungarian-Romanian bilinguals who grew up with both languages being spoken in their homes, we might conclude that in their case knowledge of Romanian facilitates the acquisition of the English passive. Yet, for the majority of L1 speakers of Hungarian from the area of Miercurea Ciuc, it seems that our hypothesis cannot be confirmed: it cannot be stated that Romanian really functions as a facilitator in the acquisition of the English passive.

\section{References}

Alberti, Gábor. 1996. Model Tau: a Formal Theory of Thematic Roles. In Zoltán Bánréti (ed.) Papers in the Theory of Grammar, 184-235. Budapest: Institute for Linguistics, Akadémiai Kiadó.

1998. On Passivization in Hungarian. In Casper de Groot-István Kenesei (eds), Papers fom the Amsterdam Conference. Approaches to Hungarian 6: 105-121. Szeged: JATE Press.

Alexiadou, Artemis. 2005. A Note on Non-Canonical Passives: The Case of the Get-Passive. In Broekhuis et al. (eds), Organizing Grammar: Linguistic Studies in Honor of Henk van Riemsdijk, 13-21. Berlin: Mouton de Gruyter.

Bartos, Huba. 2009. The Syntax of Hungarian va- Adverbial Participles. A Single Affix with Variable Merge-in Locations. In Katalin É. Kiss (ed.), Adverbs and Adverbial Adjuncts at the Interfaces, 75-102. Berlin: Mouton de Gruyter.

Bene, Annamária. 2005. Az igék bennható-mediális-tranzitív felosztásának alkalmazhatósága magyar szintaktikai és morfológiai sajátosságok magyarázatában [The Applicability of the Unergative - Unaccusative Transitive Categorization of Verbs in Explaining Syntactic and Morphological 
Properties of Hungarian]. PhD dissertation. Budapest: Eötvös Lóránd University.

Dobrovie-Sorin, Carmen. 1998. Impersonal se Constructions in Romance and the Passivization of Unergatives. Linguistic Inquiry 29: 399-439.

Groot, Casper de. 1987. On the Predicative Verbal Adverbial Construction in Hungarian. In István Kenesei (ed.), Approaches to Hungarian 2: 273-298. Szeged: JATE Press.

-1989. Predicate Structure in a Functional Grammar of Hungarian:Functional Grammar Series (11). Dordrecht: Foris Publications.

Guțu Romalo, Valeria. ed. 2005. Gramatica limbii române (GLR), I, II. [The Grammar of Romanian Language, I, II.] Bucharest: Academy Press.

Hopper, Paul-Sandra Annear Thompson. 1980. Transitivity in Grammar and Discourse. Language 56: 251-299.

Huddleston, Rodney-Pullum, Geoffrey K. 2002. The Cambridge Grammar of the English Language. Cambridge: CUP.

Kádár, Edit-Boglárka Németh. 2010. The Role of the Predicative Participle Construction in the Csángó Tense-Aspect System. Philobiblon 15: 194-225.

Kertész, Judit. 2005. Eseményszerkezet, aspektus, mondatszerkezet. A predikatív határozói igenevek [Event Structure, Aspect, Clause Structure: The Predicative Adverbial Participles]. PhD dissertation. Budapest: Eötvös Lóránd University. Laczkó, Tibor. 1995. The Syntax of Hungarian Noun Phrases. A Lexical-Functional Approach. Frankfurt: Peter Lang.

2000. A melléknévi és határozói igenévképzők [The Adjectival and Adverbial Participial Affixes]. In Ferenc Kiefer (ed.), Strukturális magyar nyelvtan, Morfológia [A Structural Grammar of Hungarian, Morphology], 409451. Budapest: Akadémiai Kiadó.

2005. Nominalization, Participle Formation, Typology, and Lexical Mapping Theory. In Christopher Piñon-Péter Siptár (eds), Approaches to Hungarian 9. Papers from the Düsseldorf Conference, 207-230. Budapest: Akadémiai Kiadó. Manoliu Manea, Maria. 1993. Gramatică, pragmasemantică şi discurs [Grammar, Pragmasemantics, and Discourse]. Bucharest: Litera.

Márkus, Andrea. 2008. Participles and the Passive in Hungarian. MA thesis. Budapest: Eötvös Lóránd University.

Németh, Boglárka. 2007. Participiul rezultativ-predicativ. O abordare aspectuală [The Predicative Verbal Adverbial Construction. An Aspectual View]. MA thesis. Cluj-Napoca: Babeş-Bolyai University.

Tankó, Enikő. 2011. The Acquisition of the English Passive Construction by L1 Speakers of Hungarian. PhD thesis. Bucharest: University of Bucharest.

- 2014. L2 Romanian Influence in the Acquisition of the English Passive by L1 Speakers of Hungarian. Acta Universitatis Sapientiae Philologica 6(2): 227248. 
2016. On the Hungarian Equivalents of the English Passive in Literary Translations. A Case Study on the Translation of Two Novels. Acta Universitatis Sapientiae Philologica 8(2): 93-107.

Tóth, Ildikó. 2000. Va- and ván- Participles in Hungarian. In Gábor, Alberti- István Kenesei (eds), Papers from the Pécs Conference. Approaches to Hungarian 7: 237-256. Szeged: JATE Press. 